\title{
Heterotrophic Utilisation of Mucilage Released During Fragmentation of Kelp (Ecklonia maxima and Laminaria pallida). I. Development of Microbial Communities Associated with the Degradation of Kelp Mucilage
}

\author{
E. A. S. Linley*, R. C. Newell* and S. A. Bosma \\ Department of Zoology, University of Cape Town, Rondebosch 7700, South Africa
}

\begin{abstract}
The micro-organisms which colonise seawater incubated with mucilage from the kelps Ecklonia maxima or Laminaria pallida show a clear succession. The media are first colonised by bacterial cocci followed by rods which are subsequently replaced by flagellates and ciliates whose combined biomass reaches some $6-10 \%$ of that of the bacteria. The maximal biomass of bacteria is achieved in $7-10 \mathrm{~d}$ incubation at $10^{\circ} \mathrm{C}$ but is dependent both on the time of appearance and biomass of the flagellate and ciliate populations. Estimates for the rate of consumption of bacteria by flagellates of only $10 \mu \mathrm{m}^{3}$ body volume suggest that mineralisation of bacteria by marine microflagellates may considerably exceed that in larger organisms at higher trophic levels.
\end{abstract}

\section{INTRODUCTION}

There have been several studies on the micro-organisms associated with the surface of marine macrophytes and sea grasses (Sieburth and Thomas, 1973; Laycock, 1974; Cundell et al., 1977; Mazure and Field, 1980). There are also many reports on the role of such micro-heterotrophs in the degradation of particulate debris (Fenchel, 1970; Meyers and Hopper, 1973; Fenchel and Jørgensen, 1976; Newell, 1979) although their quantitative significance is often difficult to assess because some studies have used plate techniques, whilst others have involved direct methods such as epifluorescence and scanning E-M observations.

Despite a recent study by Ducklow (1977) on microorganisms associated with mucus from corals, and the extensive work on freshwater and terrestrial ecosystems (Kaushik and Hynes, 1971; Lock and Hynes, 1976; Hayes, 1979), there are no studies comparable to those for particulate matter on the role of microheterotrophs in the degradation of the complex dissolved organic components released as mucilage by marine

- Present address: Institute for Marine Environmental Research, Prospect Place, Plymouth PL1 3DH, England macrophytes (Newell et al., 1980). Observations on the role of microheterotrophs in the utilisation of dissolved organic matter have been largely confined to the fate of simple ${ }^{14} \mathrm{C}$-labelled organic compounds and extracellular products from phytoplankton under culture conditions (for review see Fenchel and Jørgensen, 1976; Larsson and Hagström, 1979). The present study was therefore designed to determine the quantitative significance of microheterotrophic utilisation of exudates from kelp; it was carried out synchronously with the chemical assays described in a subsequent paper (Lucas et al., 1981). This allowed some estimates to be made of the importance of micro-organisms in the transfer of energy from the dissolved components of primary production by marine macrophytes to higher trophic levels in nearshore communities.

\section{MATERIAL AND METHODS}

Fronds of Ecklonia maxima and Laminaria pallida were collected from a kelp bed at Kommetjie on the west coast of the Cape Peninsula, South Africa, and were taken rapidly to the laboratory. Mucilage was drained from portions of the frond over a period of $6 \mathrm{~h}$ into covered sterilised funnels connected to $1 \mathrm{l}$ flasks 
held at $10^{\circ} \mathrm{C}$. Lysis of cells was encouraged by the addition of distilled water and the mucilage samples were subsequently frozen and freeze-dried. The freeze-dried mucilage was then milled to a powder and used in three series of incubation experiments each consisting of $31 \mathrm{l}$ experimental flasks containing mucilage powder, and freshly collected coarse filtered $(62 \mu \mathrm{m})$ seawater from Kommetjie.

Additions of dry mucilage to the seawater were based on earlier analyses of mucilage and on the wet weight:dry weight ratio of mucilage (Newell et al., 1980 ) to give a 1:10 dilution of the original wet mucilage in seawater. Two experimental series were set up using seawater collected in August (winter); one contained $6.4 \mathrm{~g} \mathrm{l}^{-1}$ mucilage from Ecklonia maxima and the other contained $7.2 \mathrm{~g} \mathrm{l}^{-1}$ mucilage from Laminaria pallida. A third also contained $7.2 \mathrm{~g} \mathrm{l}^{-1}$ mucilage from L. pallida but was incubated with seawater from the kelp bed collected during January (summer). Control flasks containing coarse filtered seawater from the same source were set up for each mucilage incubation.

Incubation vessels were held at $10^{\circ} \mathrm{C}$, illuminated with a $12 \mathrm{~h}$ light:dark regime and aerated by means of a pump which drew $0.2 \mu \mathrm{m}$ filtered air through the vessels in series. Maintenance of a sterile air flow was ensured by inserting a flask containing $0.2 \mu \mathrm{m}$ filtered and autoclaved seawater after the air supply and monitoring this at daily intervals by AODC. Contamination between successive vessels was minimised by inserting cottol wool plugs into the connecting tubes between each vessel, and by placing the unsterilised flasks last in the series.

Daily samples were taken into sterile $20 \mathrm{ml}$ scintillation vials for AODC of micro-organisms, scanning electron microscopy, and for analysis of the chemical composition of the incubation media. These latter data are reported in a subsequent paper by Lucas et al. (1981).

\section{Assessment of Micro-Organism Numbers and Biomass}

The epifluorescence technique of acridine orange direct counting (AODC) is widely considered to be the most reliable method of estimating the numbers of free-living micro-organisms (Jones and Simon, 1975; Bowden, 1977; Hobbie et al., 1977) and it seems likely that this method has yielded accurate data where cell densities are comparable with those in natural environments. However, the addition of dried kelp mucilage to natural seawater created two main conditions which made AODC difficult to perform. First, during the early stages of incubation bacteria remained embedded in, and obscured by, colloidal mucus. Sec- ond, as densities increased to $10^{7}-10^{8}$ cells $\mathrm{ml}^{-1}$ following utilisation of the mucilage, time-consuming dilutions and adjustments to stain concentration became necessary, probably incurring further inaccuracies. However, counts performed from scanning electron micrographs of mucilage enriched samples demonstrated good agreement between the two methods for assessing numbers of micro-organisms (see also Bowden, 1977). Consequently, the AODC method has been used throughout for counting microorganisms, and scanning electron micrographs for their identification and measurement of cell dimensions for biomass estimates.

\section{Acridine Orange Direct Counts of Micro-Organisms}

The method for staining micro-organisms with acridine orange was modified from that of Hobbie et al. (1977; see also Field et al., 1980). Known volumes of sample were incubated in a sterile test tube for $3 \mathrm{~min}$ with an equal volume of aqueous acridine orange (10 $\mathrm{mg} \mathrm{l}^{-1}$ ) fixed with $4 \% 0.45 \mu \mathrm{m}$ filtered formaldehyde (final concentration) to inhibit bacterial growth. Where necessary, the samples were diluted with $0.2 \mu \mathrm{m}$ filtered sterile seawater. Controls of stain plus dilution water were run daily. Meanwhile polycarbonate Nuclepore filters ( $47 \mathrm{~mm}$ diameter; $0.2 \mu \mathrm{m}$ pore size) were stained before use to reduce background fluorescence by soaking for $10 \mathrm{~min}$ in $2 \mathrm{~g}$ Irgalan Black $1^{-1}$ of $2 \%$ acetic acid (Hobbie et al., 1977). The filters were then rinsed twice in distilled water and kept covered in distilled water until use.

Filtration was carried out on Millipore pads (AP 1004751) with a few drops of $1 \%$ Photoflo placed above and below the filter as a surfactant. A vacuum was applied to wet the filter and the sample was filtered using a vacuum of less than $0.8 \mathrm{~atm}$. The moist filters were stored on damp pads prior to use. Portions of the filter were then placed on a drop of non-fluorescent low viscosity immersion ail on a glass microscope slide, a drop of oil was placed on top, and the filter covered with a glass cover slip. Bacteria were viewed at a magnification of $1000 \times$ with a Zeiss microscope fitted with an epifluorescence condenser, HBO $50 \mathrm{~W}$ mercury burner, 455-500 band-pass exciter filter, 510 beam splitter and LP 520 barrier filter. The field diameter was adjusted so that 15-30 bacteria were viewed and the numbers $(\mathrm{N}$ ) calculated from counts of 20 randomly-chosen fields using the expression:

$$
\mathrm{N}=\frac{\mathrm{s} \times 10^{6} \times \mathrm{n}}{\mathrm{s} \times \mathrm{V}} \text { cells } \mathrm{ml}^{-1}
$$

where $S=$ working surface area of the filter, $\mathrm{mm}^{2} ; \mathrm{s}=$ surface area of the field of observation, $u \mathrm{~m}^{2} ; \mathrm{V}=$ 
volume of sample filtered, $\mathrm{ml} ; \mathrm{n}=$ average number of cells per field.

\section{Scanning Electron Microscopy}

Preparation of seawater and mucilage enriched samples for scanning electron microscopy was based on a combination of methods described by Paerl (1975), Bowden (1977), and Todd and Kerr (1972). Samples of $20 \mathrm{ml}$ were placed in autoclaved scintillation vials and glutaraldehyde added to a final concentration of $1.5 \%$. The fixed samples were stored in the dark at $5^{\circ} \mathrm{C}$ prior to use. Known volumes of sample were filtered onto $25 \mathrm{~mm}$ diameter polycarbonate Nuclepore membranes with $0.2 \mu \mathrm{m}$ pore diameter. Cores of $1 \mathrm{~cm}$ diameter were punched in the damp membranes and inserted between two ring magnets, to hold the filter taut, and immediately transferred to $100 \%$ artificial seawater. The samples were desalinated by holding for $10 \mathrm{~min}$ each in 90, 75, 50, and $25 \%$ artificial seawater plus distilled water which had been autoclaved and filtered through a $0.2 \mu \mathrm{m}$ filter prior to use, followed by two washes of distilled water. The samples were then dehydrated by holding for $30 \mathrm{~min}$ in each of an ascending alcohol series increasing in $10 \%$ steps from $10 \%$ to $100 \%$ and ending in a final wash in $100 \%$ ethanol. Finally, the samples were critical point dried (see Anderson, 1951), mounted on SEM stubs, sputter coated with $200 \AA$ gold paladium, and stored in a desiccator until viewed with a Cambridge Stereoscan 180 scanning electron microscope, at an accelerating voltage of $25 \mathrm{kV}$.

Scanning electron micrographs were used to determine the relative numbers of rods and cocci, measure cell dimensions and estimate the average volume of rods and cocci, diatoms, flagellates and ciliates. Biomass was then calculated from cell numbers (N) using the expression described on p. 32 .

$$
\text { Wet Biomass }=\frac{[(\mathrm{NrVr})+(\mathrm{NcVc})] \times \mathrm{S} . \mathrm{G}}{10^{6}}
$$

where $\mathrm{N}=$ the number of cells. $\mathrm{ml}^{-1}\left(\times 10^{6}\right) ; \mathrm{V}=$ the mean volume of the cells $\left(\mu \mathrm{m}^{3}\right) ; \mathrm{S} . \mathrm{G}=$ the specific gravity of the cells; $\mathrm{r}=$ rods; $\mathrm{c}=$ cocci.

The specific gravity of bacteria was assumed to be 1.1 (Luria, 1960) whilst that of flagellates and diatoms was taken to be similar to that of Dunaliella, which has a mean specific gravity of 1.0425 , whilst that of ciliates was taken to be similar to that of Paramecium which has a mean specific gravity of 1.0375 (Calkins and Summers, 1941). The mean volumes of bacteria were similar in media containing mucilage from both Ecklonia maxima and Laminaria pallida, but varied considerably in winter and summer incubation experi- ments $\left(0.14 \mu \mathrm{m}^{3}\right.$ and $0.44 \mu \mathrm{m}^{3}$, respectively). Volumes of flagellates were in the range of 2.57 to $57.91 \mu \mathrm{m}^{3}$; of ciliates, 10.55 to $1363 \mu^{3}$. Dry biomass and the carbon equivalent of the wet biomass can be calculated using the coefficients 0.2 and 0.1, respectively (Luria, 1960; Troitsky and Sorokin, 1967; see also Sorokin and Kadota, 1972).

\section{RESULTS}

\section{Microbial Communities Associated with the Degradation of Kelp Mucilage}

Two major series of experiments were carried out on the micro-organisms associated with kelp mucilage cultured in the laboratory in seawater freshly collected from the kelp bed at Kommetjie, on the west coast of the Cape Peninsula, South Africa. The first series was carried out over periods of $10 \mathrm{~d}$ in August 1979 (winter) using the combination of AODC and SEM techniques described on p. 32. During this and other incubation work it became apparent that a longer culture period was desirable since some organisms such as ciliates appeared in the cultures during the last few days of the incubation period. Mazure (1978) has also found a definite seasonality in species composition and relative abundance of morphological types in the microbial community of kelp bed seawater. In the winter bacterial numbers are low and are dominated by cocci whereas in summer bacterial numbers are higher and species composition may be different to that in winter. The types of micro-organisms in the initial inoculum may thus largely determine the nature of the assemblage which develops following the addition of kelp mucilage under laboratory conditions. A second series of experiments was therefore carried out using the same medium, but seawater collected from the kelp bed in February 1980 (summer) and incubated over a period of $28 \mathrm{~d}$.

\section{Winter Incubation Experiments}

The results of the first series of incubation experiments are summarised in Table 1 which shows the counts of micro-organisms in control vessels of seawater freshly collected from the kelp bed in winter, and in seawater samples which had been enriched with either $6.4 \mathrm{~g} \mathrm{l}^{-1}$ dried mucilage from Ecklonia maxima or $7.2 \mathrm{~g}$ $\mathrm{l}^{-1}$ mucilage from Laminaria pallida, respectively.

Seawater control samples contained mainly a mixed assemblage of small bacterial rods and cocci which increased in numbers from approximately $1.5 \times 10^{6}$ cells $\mathrm{ml}^{-1}$ to $6.9 \times 10^{6}$ cells $\mathrm{ml}^{-1}$ over a period of $7 \mathrm{~d}$ incubation at $10^{\circ} \mathrm{C}$ and subsequently declined, until 
Table 1. Number of micro-organisms (cells $\mathrm{ml}^{-1}$ ) in filtered samples taken daily for $10 \mathrm{~d}$ from incubated seawater controls and from media to which dried mucilage at a concentration of $6.4 \mathrm{~g}^{-1}$ from Ecklonia maxima and $7.2 \mathrm{~g} \mathrm{l}^{-1}$ from Laminaria pallida had been added. Asterisk: time at which flagellates were first noted but not abundant enough to be sampled quantitatively

\begin{tabular}{|c|c|c|c|c|c|c|c|c|}
\hline \multirow[t]{2}{*}{ Day } & \multicolumn{3}{|c|}{ Seawater control } & \multicolumn{5}{|c|}{ Seawater + mucilage } \\
\hline & $\begin{array}{l}\text { Bacteria } \\
\times 10^{6}\end{array}$ & $\begin{array}{c}\text { Flagellates } \\
\times 10^{4}\end{array}$ & Diatoms & Rods $\times 10^{6}$ & $\begin{array}{c}\text { Bacteria } \\
\text { Cocci } \times 10^{6}\end{array}$ & Total $\times 10^{6}$ & $\begin{array}{c}\text { Flagellates } \\
\times 10^{4}\end{array}$ & Diatoms \\
\hline \multicolumn{9}{|c|}{ Ecklonia maxima } \\
\hline 1 & 0.47 & - & - & 1.79 & 0.27 & 2.06 & - & - \\
\hline 2 & 0.59 & - & - & 3.52 & 0.62 & 4.14 & - & - \\
\hline 3 & 0.56 & - & - & 64.85 & 6.41 & 71.26 & - & - \\
\hline 4 & 1.21 & - & 117 & 265.9 & 58.4 & 324.3 & - & - \\
\hline 5 & 5.28 & - & 345 & 499.4 & 157.7 & 657.1 & - & - \\
\hline 6 & 2.57 & 4.37 & 2028 & 513.3 & 105.1 & 618.4 & ${ }_{-}^{*}$ & - \\
\hline 7 & 2.75 & 4.25 & 6439 & 605.9 & 247.6 & 853.5 & 10.4 & - \\
\hline 8 & 0.47 & 4.62 & 8451 & 573.1 & 201.3 & 774.4 & 16.0 & - \\
\hline 9 & 0.51 & 8.03 & 9054 & 343.1 & 201.5 & 544.6 & 29.3 & - \\
\hline 10 & 0.73 & 10.39 & 9037 & 62.6 & 76.5 & 139.1 & 68.5 & - \\
\hline \multicolumn{9}{|c|}{ Laminaria pallida } \\
\hline 1 & 0.64 & 0.28 & - & 1.30 & 0.61 & 1.91 & - & -- \\
\hline 2 & 1.50 & 0.69 & - & 2.24 & 3.09 & 5.33 & - & - \\
\hline 3 & 2.57 & 1.75 & - & 132.5 & 108.4 & 240.9 & - & - \\
\hline 4 & 6.53 & 1.98 & - & 26.78 & 508.8 & 535.6 & - & - \\
\hline 5 & 3.51 & 2.08 & - & 322.9 & 411.0 & 733.9 & - & - \\
\hline 6 & 1.57 & 4.10 & 663 & 520.1 & 84.7 & 604.8 & - & - \\
\hline 7 & 9.13 & 3.76 & 897 & 606.9 & 107.1 & 714.0 & $\cdot$ & - \\
\hline 8 & 0.77 & 2.93 & 6660 & 516.6 & 181.5 & 698.1 & 30.3 & - \\
\hline 9 & 0.60 & - & 7747 & 17.11 & 29.14 & 46.25 & 144.0 & - \\
\hline 10 & 6.70 & - & 13730 & 15.96 & 33.93 & 49.89 & 1490 & - \\
\hline 11 & 8.76 & - & 17588 & 10.72 & 26.23 & 36.95 & 99.5 & - \\
\hline
\end{tabular}

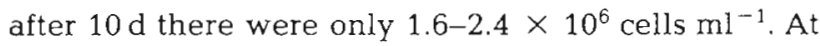
the same time, a mixed population of flagellates, including phototrophic forms similar to Micromonas and Mallomonas, increased from approximately $0.3 \times$ $10^{4}$ to $10.4 \times 10^{4}$ cells $\mathrm{ml}^{-1}$ over a period of $10 \mathrm{~d}$. The principal genera of diatoms included Nitzschia, Thalassiosira, Asterionella (A. glacialis), and Skeletonema; the population was low or absent during the first $4 \mathrm{~d}$ but increased to as many as $17.6 \times 10^{3}$ cells $\mathrm{ml}^{-1}$ over the $10 \mathrm{~d}$ incubation period. Acridine orange direct counts of the assemblage of micro-organisms thus show some indication of a sequential succession of bacteria, flagellates and diatoms under culture conditions in control vessels containing freshly collected seawater from the kelp bed.

The effects of the addition of $6.4 \mathrm{~g} \mathrm{l}^{-1}$ of dried mucilage from Ecklonia maxima and $7.2 \mathrm{~g}^{-1}$ from Laminaria pallida are shown in Table 1. It is evident that both the numbers and variety of organisms are affected by the presence of added kelp mucilage. Bacterial numbers were almost $100 \times$ higher than in control samples and reached their maximum abundance on Day 7-8 before declining. Further, there is some indication, especially in samples incubated with mucilage from $L$. pallida, that cocci reach their peak abundance and decline before the rods become abundant. Flagellates occurred only at the end of the experimental period and, like the bacteria, reached higher numbers than in the control vessels. They were mainly represented by phagotrophic and creeping forms similar to Bodo edax and Rynchomonas nausta (Sieburth, 1979). Finally, diatoms failed to appear in either series of vessels, but occasional ciliates were observed towards the end of the $10 \mathrm{~d}$ incubation period. A series of scanning electron micrographs of typical elements of the microbial succession which develops in the presence of kelp mucilage is shown in Figure 1.

The results suggest, therefore, that the addition of kelp mucilage to a concentration of approximately $6.4-7.2 \mathrm{~g} \mathrm{l}^{-1}$ results in the inhibition of some components of the mixed assemblage of micro-organisms in natural seawater, and at the same time provides a substrate for the rapid development of a large population of bacterial rods and cocci. These, rather than the dissolved organic matter from the kelp mucilage, may then provide an energy resource for other heterotrophs, including the flagellates which appear at a later stage in the incubation experiments. Whether the sequential development of rods and cocci, and their decline after 
$8 \mathrm{~d}$, coincides with the utilisation of one or all of the substrates available in the mucilage is reported in a subsequent paper (Lucas et al, 1981). It is significant, however, that incubation for up to $30 \mathrm{~d}$ in $5.8 \mathrm{~g} \mathrm{l}^{-1}$ mannitol, which is one important component of kelp mucilage (Newell et al., 1980), results in no significant increase in bacterial numbers compared with natural seawater. This suggests that some other component of

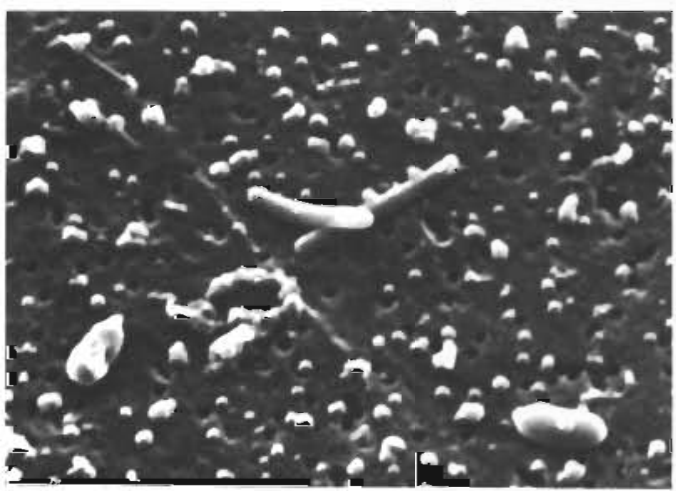

a $-1 \mu \mathrm{m}$

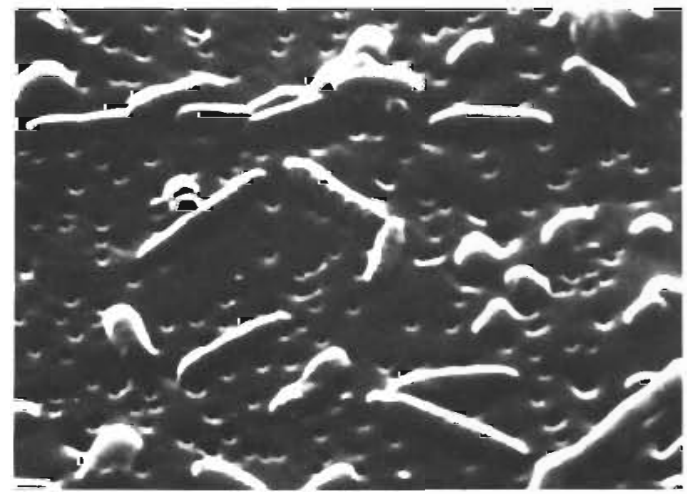

c $\quad-1 \mu \mathrm{m}$

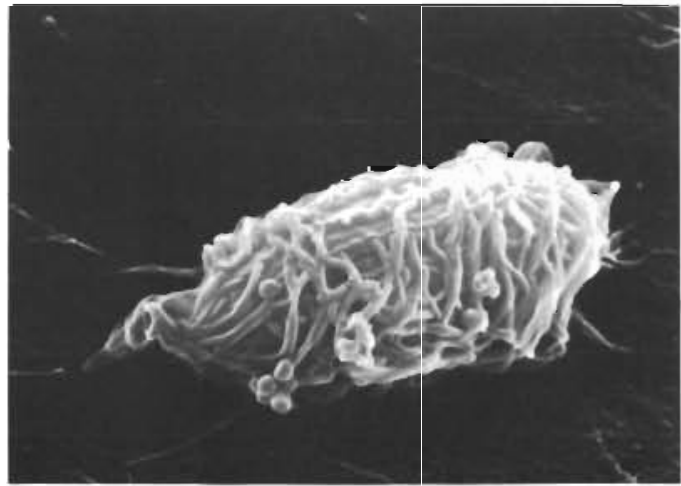

e

$3 \mu \mathrm{m}$ kelp mucilage, such as available nitrogen, may act as a limiting resource for the bacteria which colonised the mucilage in our incubation experiments. A rather similar result has been obtained by Ducklow (1977) who found that the number of colonies of Vibrio alginolyticus per ml of culture containing mucilage from the coral Heteroxenia was approximately 150 times that in glucose medium.
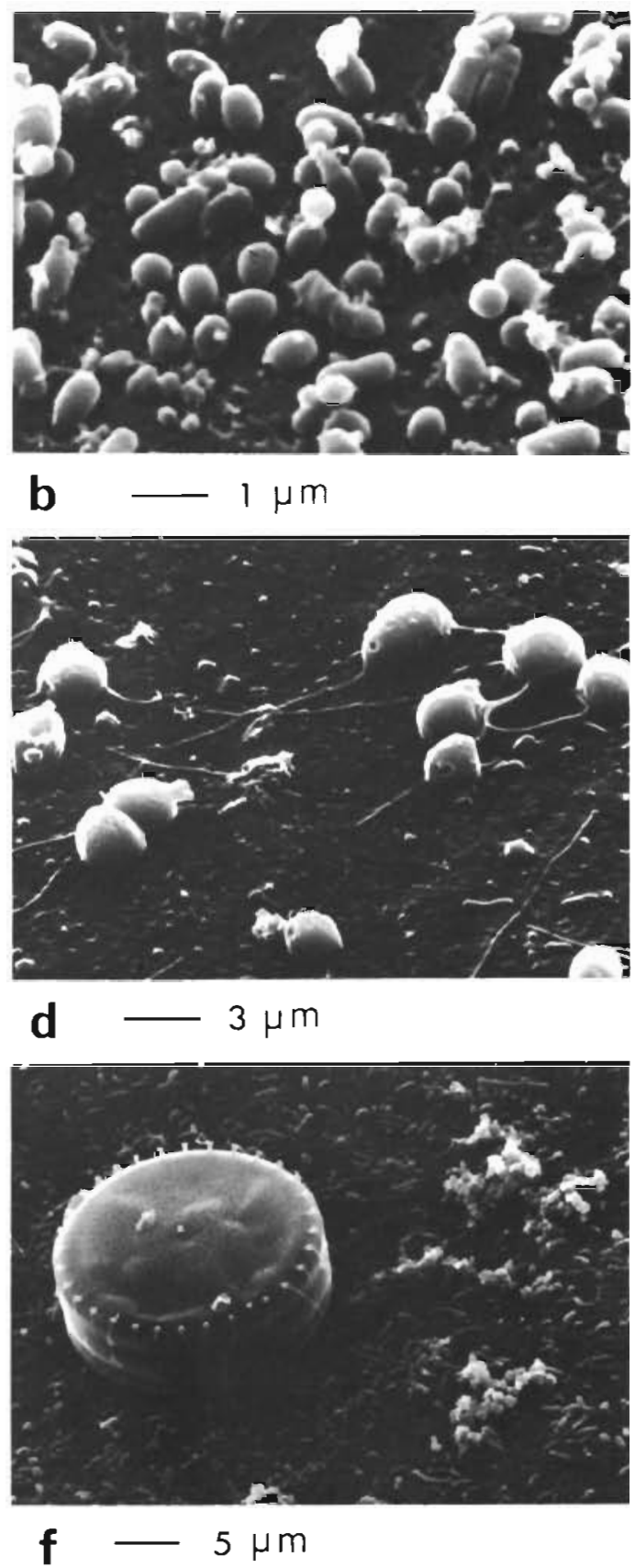

Fig. 1. A selection of micro-organisms from incubation experiments. (a) Population of cocci which dominate the Laminaria pallida mucilage media during the winter. (b) Rods and cocci on Ecklonia maxima mucilage. (c) Large rods in early stages of incubation of L. pallida mucilage during summer. (d) Phagotrophic flagellates. (e) Ciliate with attached cocci. (f) Thalassiosira sp. and mixed bacterial population in sea-water control 
Table 2. Number of micro-organisms (cells $\mathrm{ml}^{-1}$ ) on filtered samples taken daily for $28 \mathrm{~d}$ from incubated seawater controls and from seawater to which $7.2 \mathrm{~g} \mathrm{l}^{-1}$ dried mucilage from Laminaria pallida had been added at the beginning of the incubation period

\begin{tabular}{|c|c|c|c|c|c|c|c|c|}
\hline \multirow[t]{2}{*}{ Day } & \multicolumn{4}{|c|}{ Seawater control } & \multicolumn{4}{|c|}{ Seawater + mucilage } \\
\hline & $\begin{array}{l}\text { Bacterla } \\
\quad \times 10^{1}\end{array}$ & $\begin{array}{l}\text { Flagellates } \\
\quad \times 10^{4}\end{array}$ & $\begin{array}{c}\text { Ciliates } \\
\times 10^{2}\end{array}$ & $\begin{array}{l}\text { Diatoms } \\
\times 10^{4}\end{array}$ & $\begin{array}{c}\text { Bacteria } \\
\times 10^{\circ}\end{array}$ & $\begin{array}{c}\text { Flagellates } \\
\times 10^{4}\end{array}$ & $\begin{array}{c}\text { Ciliates } \\
\times 10^{3}\end{array}$ & Diatoms \\
\hline 1 & 0.96 & - & - & - & 7.43 & - & - & - \\
\hline 2 & 1.17 & - & - & - & 11.1 & - & - & - \\
\hline 3 & 1.98 & - & - & - & 37.4 & - & - & - \\
\hline 4 & 2.35 & - & - & - & 206.0 & - & - & - \\
\hline 5 & 4.97 & 0.17 & - & 0.06 & 251.0 & - & - & - \\
\hline 6 & 6.48 & 0.53 & - & 0.11 & 234.0 & - & - & - \\
\hline 7 & 9.02 & 1.58 & - & 0.62 & 346.0 & - & - & - \\
\hline 8 & 6.87 & 2.33 & - & 0.93 & 466.0 & - & - & - \\
\hline 9 & 5.73 & 2.63 & - & 1.59 & 598.0 & - & - & - \\
\hline 10 & 5.91 & 4.15 & - & 1.63 & 490.0 & - & 1.14 & - \\
\hline 11 & 7.13 & 4.41 & - & 1.69 & 417.0 & 1.79 & 4.73 & - \\
\hline 12 & 7.42 & 4.27 & 1.23 & 1.04 & 382.0 & 2.83 & 13.5 & - \\
\hline 13 & 6.07 & 2.93 & 2.17 & 0.74 & 211.0 & 15.1 & 18.1 & - \\
\hline 14 & 4.93 & 2.71 & 1.95 & 0.21 & 4.96 & 20.0 & 31.4 & - \\
\hline 15 & 2.19 & 0.24 & 1.31 & - & 4.42 & 18.1 & 25.2 & - \\
\hline 16 & 1.21 & - & 2.04 & - & 34.5 & 24.4 & 28.1 & - \\
\hline 17 & 0.74 & - & 1.12 & - & 11.4 & 4.71 & 43.6 & - \\
\hline 18 & 0.52 & - & - & - & 1.54 & 4.46 & 42.0 & - \\
\hline 19 & 0.25 & - & - & - & 1.59 & 10.70 & 21.5 & - \\
\hline 20 & 0.20 & - & - & - & 1.19 & 18.10 & 3.70 & - \\
\hline 21 & 0.17 & - & - & - & 2.10 & 13.30 & 4.44 & - \\
\hline 22 & 0.11 & - & -- & - & 2.73 & 6.73 & 3.75 & - \\
\hline 23 & 0.15 & - & - & - & 2.96 & 5.25 & 2.50 & - \\
\hline 24 & 0.18 & - & - & - & 2.37 & 5.92 & 2.12 & - \\
\hline 25 & 0.22 & - & - & - & 2.11 & 4.83 & 2.37 & - \\
\hline 26 & 0.24 & - & - & - & 2.52 & 4.47 & 2.32 & - \\
\hline 27 & 0.28 & - & - & - & 2.81 & 1.77 & 3.14 & - \\
\hline 28 & 0.21 & - & - & - & 2.35 & 1.50 & 2.35 & - \\
\hline
\end{tabular}

\section{Summer Incubation Experiments}

The succession of micro-organisms, developing in the seawater - collected in summer, containing $7.2 \mathrm{~g}$ $1^{-1}$ of dried mucilage from Laminaria pallida and incubated for $28 \mathrm{~d}$ - is shown in Table 2. As in earlier incubation experiments, an initial major increase in bacterial numbers is apparent which after $5 \mathrm{~d}$ becomes dominated by large rods with a mean volume of $0.49 \mu \mathrm{m}^{3}$. The population of bacteria reached its maximum abundance in $9 \mathrm{~d}$ after which it declined and was replaced by a population of flagellates (mainly organisms similar to Monas, Oikomonas, Bodo and Rynchomonas) and ciliates (including types similar to Uronema, Cyclidium and Euplotes). The elements of the microbial succession noted in the winter seawater samples thus occur in the summer seawater incubation experiments but ciliates, which were noted only in the later stages of the winter samples, emerged as the major organisms $\left(\mathrm{mg} \mathrm{l}^{-1}\right.$ ) by Day 14 of the summer incubation. The relative abundance of the different components of the microbial community over the incu- bation period of $28 \mathrm{~d}$ is summarised in Figure 2 and shows a good correspondence with the numbers of bacteria, flagellates and ciliates which develop on particulate debris from the marine grass Thalassia (Fenchel, 1970).

\section{Biomass of Micro-Organisms Associated with the Degradation of Kelp Mucilage}

Although the numbers of micro-organisms which develop in the incubation media show a clear succession with maximal bacterial numbers after $7-9 \mathrm{~d}$ followed by an increase in the flagellate and ciliate populations, the data give little indication of the energy transfer unless the micro-organism biomass is known. This can be calculated from the cell numbers, dimensions, and the specific gravity of the component cells (see p. 33)

The biomass figures calculated from AODC counts and SEM measurements of cell dimensions in the seawater samples containing $6.4-7.2 \mathrm{~g} \mathrm{l}^{-1}$ of mucilage 


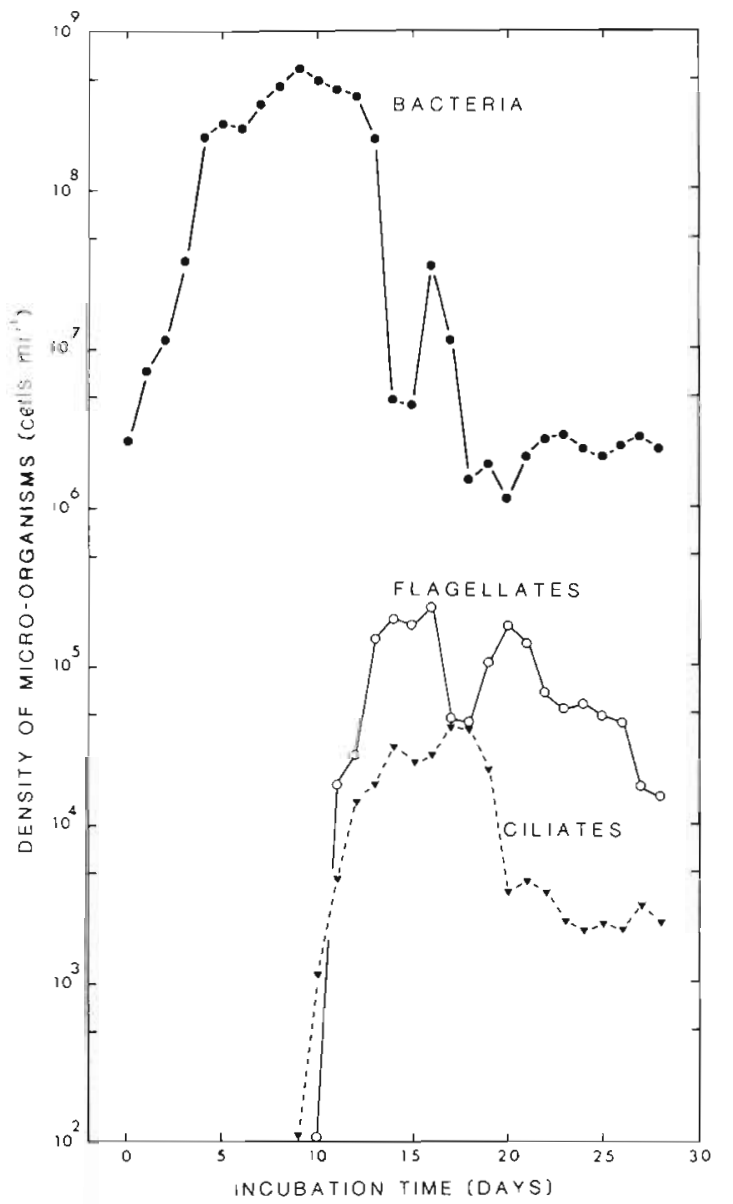

Fig. 2. Numbers of micro-organisms (cells $\mathrm{ml}^{-1}$ ) developing over a period of $28 \mathrm{~d}$ in incubation media at $10^{\circ} \mathrm{C}$, to which $7.2 \mathrm{~g} \mathrm{l}^{-1}$ of dried mucilage from Laminaria pallida $(=2.185 \mathrm{~g}$ $1^{-1}$ organic matter) had been added

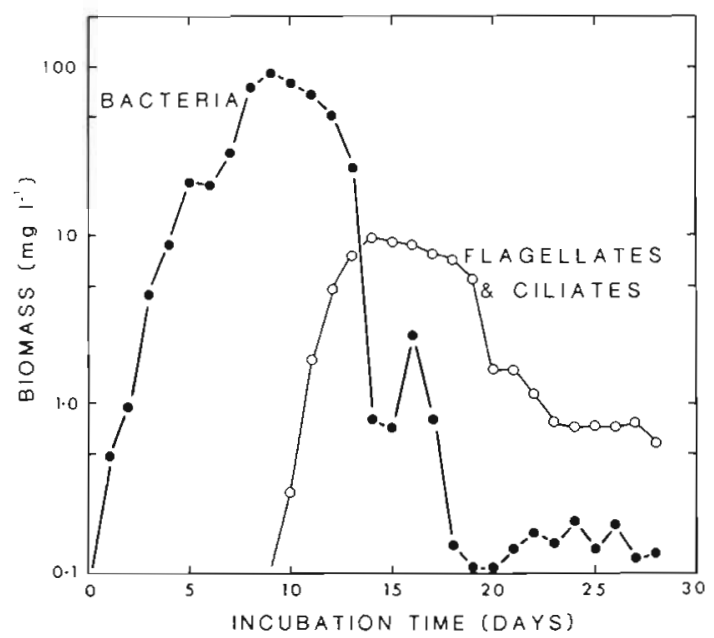

Fig. 3. Biomass of micro-organisms (mg $\left.\mathrm{l}^{-1}\right)$ developing over a period of $28 \mathrm{~d}$ in incubation media at $10^{\circ} \mathrm{C}$, to which $7.2 \mathrm{~g} \mathrm{l}^{-1}$ of dried mucilage from Laminaria pallida $\left(=2.185 \mathrm{~g}^{-1}\right.$ organic matter) had been added from Ecklonia maxima and Laminaria pallida are shown in Table 3 . It is evident that the rods dominate the bacterial biomass in the winter seawater samples and account for the major component of the total

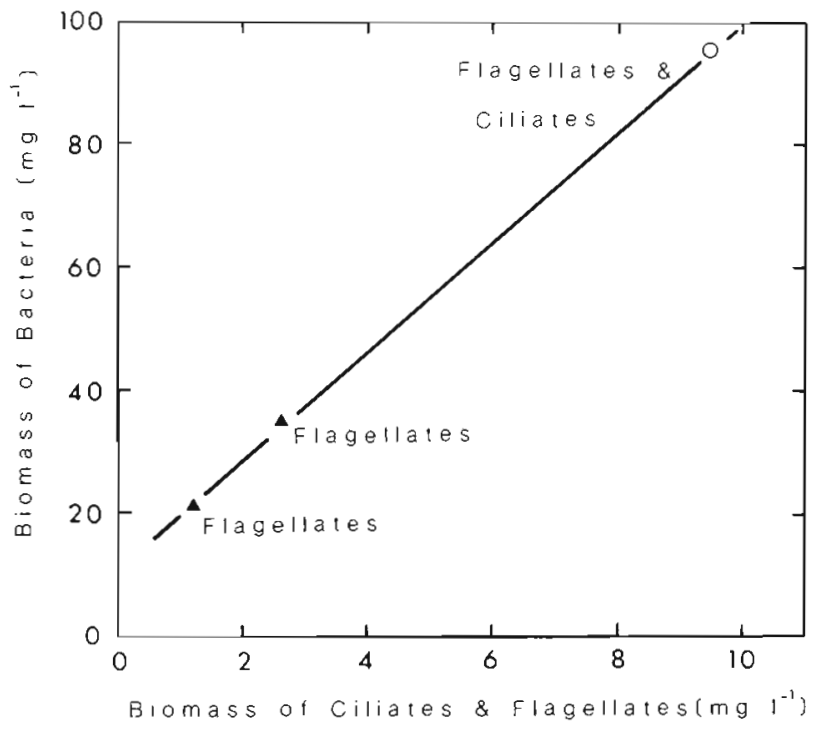

Fig. 4. Relationship between maximum biomass formed by bacteria and the biomass of flagellates and ciliates in cultures containing approximately $2 \mathrm{~g} \mathrm{l}^{-1}$ organic matter from kelp (Ecklonia maxima and Laminaria pallida) mucilage in seawater at $10^{\circ} \mathrm{C}$. Compiled from Table 5. Equation of regression $Y=8.96 X+10.91 ; r=0.9998$

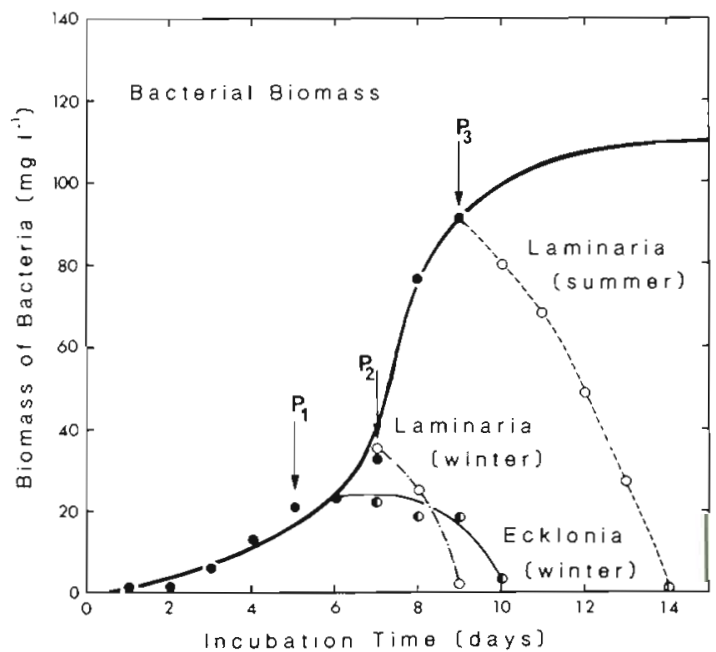

Fig. 5. Pooled data for biomass of bacteria ( $\mathrm{mg}^{-1}$ ) developing as a function of time in incubation media containing approximately $2 \mathrm{~g} \mathrm{l}^{-1}$ organic matter from kelp (Ecklonia maxima and Laminaria pallida) mucilage in seawater at $10{ }^{\circ} \mathrm{C}$. Curve fitted to the pooled data for incubation experiments before appearance of Protozoa. Biomass of bacteria following the appearance of Protozoa in each incubation experiment is also shown. $\mathrm{P}_{1}, \mathrm{P}_{2}$, and $\mathrm{P}_{3}$ indicate first appearance of grazing Protozoa in each of the 3 incubation experiments. Compiled from Tables 3 and 4 


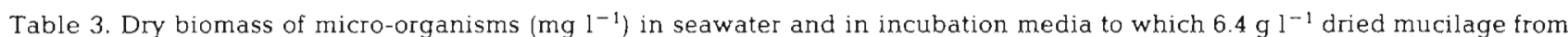
Ecklonia maxima and $7.2 \mathrm{~g} \mathrm{l}^{-1}$ from Laminaria pallida had been added. Asterisk: appearance of flagellates, not yet sufficiently abundant to be assessed quantitatively. Net total heterotroph biomass obtained by subtraction of total heterotroph biomass in seawater controls from those to which mucilage had been added

\begin{tabular}{|c|c|c|c|c|c|c|c|c|c|c|c|}
\hline \multirow{2}{*}{ Days } & \multicolumn{4}{|c|}{ Seawater control } & \multicolumn{6}{|c|}{ Seawater + mucilage } & \multirow{2}{*}{$\begin{array}{c}\text { Net total } \\
\text { hetero- } \\
\text { trophs }\end{array}$} \\
\hline & Bacteria & $\begin{array}{l}\text { Flagel- } \\
\text { lates }\end{array}$ & Diatoms & $\begin{array}{l}\text { Total he- } \\
\text { terotrophs }\end{array}$ & Rods & Cocci & $\begin{array}{c}\text { Total } \\
\text { bacteria }\end{array}$ & $\begin{array}{c}\text { Flagel- } \\
\text { lates }\end{array}$ & Diatoms & $\begin{array}{l}\text { Total he- } \\
\text { terotrophs }\end{array}$ & \\
\hline \multicolumn{12}{|c|}{ Ecklonia maxima } \\
\hline 1 & 0.009 & - & - & 0.009 & 0.047 & 0.022 & 0.049 & - & - & 0.049 & 0.040 \\
\hline 2 & 0.013 & - & - & 0.013 & 0.101 & 0.007 & 0.108 & - & - & 0.108 & 0.095 \\
\hline 3 & 0.016 & - & - & 0.016 & 2.299 & 0.085 & 2.384 & - & - & 2.384 & 2.368 \\
\hline 4 & 0.022 & - & 0.020 & 0.022 & 11.116 & 0.642 & 11.758 & - & - & 11.758 & 11.736 \\
\hline 5 & 0.144 & - & 0.057 & 0.144 & 18.677 & 2.776 & 21.453 & - & - & 21.453 & 21.309 \\
\hline 6 & 0.105 & 0.122 & 0.320 & 0.105 & 14.680 & 1.388 & 16.068 & $-{ }^{\cdot}$ & - & $(16.068)$ & 15.963 \\
\hline 7 & 0.131 & 0.118 & 0.974 & 0.131 & 19.998 & 2.178 & 22.176 & 0.333 & - & 22.509 & 22.378 \\
\hline 8 & 0.022 & 0.128 & 1.319 & 0.022 & 16.389 & 2.215 & 18.604 & 0.512 & - & 19.116 & 19.094 \\
\hline 9 & 0.009 & 0.224 & 1.532 & 0.009 & 14.341 & 4.876 & 19.217 & 0.938 & - & 20.155 & 20.146 \\
\hline 10 & 0.013 & 0.290 & 1.639 & 0.013 & 2.066 & 1.515 & 3.581 & 1.433 & - & 5.014 & 5.001 \\
\hline \multicolumn{12}{|c|}{ Laminaria pallida } \\
\hline 1 & 0.032 & 0.009 & - & 0.032 & 0.060 & 0.007 & 0.067 & - & - & 0.067 & 0.035 \\
\hline 2 & 0.045 & 0.022 & - & 0.045 & 0.108 & 0.075 & 0.183 & - & - & 0.183 & 0.138 \\
\hline 3 & 0.085 & 0.056 & - & 0.085 & 8.450 & 3.100 & 11.550 & - & - & 11.550 & 11.465 \\
\hline 4 & 0.157 & 0.064 & - & 0.157 & 1.826 & 17.91 & 19.736 & - & - & 19.736 & 19.579 \\
\hline 5 & 0.061 & 0.067 & - & 0.061 & 17.760 & 1.808 & 19.568 & - & - & 19.568 & 19.507 \\
\hline 6 & 0.023 & 0.132 & 0.010 & 0.023 & 24.030 & 1.304 & 25.334 & - & - & 25.334 & 25.311 \\
\hline 7 & 0.070 & 0.121 & 0.148 & 0.070 & 33.380 & 1.649 & 35.029 & - & - & 35.029 & 34.959 \\
\hline 8 & 0.012 & 0.094 & 1.195 & 0.012 & 22.730 & 2.396 & 25.126 & $0.635^{\circ}$ & - & 25.761 & 25.749 \\
\hline 9 & 0.017 & - & 1.380 & 0.017 & 0.791 & 1.154 & 1.945 & 2.759 & - & 4.704 & 4.687 \\
\hline 10 & 0.123 & - & 2.418 & 0.123 & 0.632 & 0.821 & 1.453 & 2.855 & - & 4.308 & 4.185 \\
\hline 11 & 0.157 & - & 3.006 & 0.157 & 0.495 & 0.173 & 0.668 & 1.906 & - & 2.574 & 2.417 \\
\hline
\end{tabular}

heterotroph biomass, even though their mean volume $\left(0.28 \mu \mathrm{m}^{3}\right)$ was rather small compared with the surnmer forms $\left(0.49 \mu \mathrm{m}^{3}\right)$.

The longer term measurements made on seawater samples collected and incubated with Laminaria mucilage during the summer are summarised in Table 4. Despite the similarity in numbers and time sequence of microheterotroph organisms to those which occur in the winter samples, the differences in bacterial biomass are striking. The three-fold increase in bacterial biomass in summer over winter samples is mainly attributable to the larger size of the bacterial rods, whose mean volume was $0.49 \mu \mathrm{m}^{3}$. Bacteria thus dominated the community, especially over the first $12-13 \mathrm{~d}$, and were subsequently replaced by a mixed assemblage of flagellates and ciliates which together attained a maximum biomass of approximately $11 \%$ of that of the bacteria on Day 14.

It is significant that, as is shown in Figure 3, the decline in bacterial biomass coincided with the appearance of ciliates and flagellates, many of which are known to graze on bacteria (see Fenchel, 1969, 1970) and which probably limit the bacterial biomass in the incubation media.

\section{Conversion of Kelp Mucilage to Heterotroph Biomass}

The data summarised in Tables 3 and 4 showing the dry biomass of micro-organisms in seawater controls and in incubation media to which mucilage from Ecklonia maxima and Laminaria pallida had been added may be used to estimate the conversion of kelp mucilage into bacteria and Protozoa through the microheterotrophic food chain. Tables 3 and 4 additionally show the net increase in microbial biomass following the addition of $6.4 \mathrm{~g} \mathrm{l}^{-1}$ dried mucilage from E. maxima and $7.2 \mathrm{~g} \mathrm{l}^{-1}$ from L. pallida over a period of $10 \mathrm{~d}$ in the winter incubation series and up to $28 \mathrm{~d}$ for the summer series.

The maximal bacterial biomass is formed in some $7-10 \mathrm{~d}$, but is clearly dependent on both the time of appearance and biomass of the flagellate and ciliate populations. In the winter incubation experiments, for example, flagellates appeared on Day 5.5 in the EckIonia maxima mucilage incubation and became sufficiently abundant on Day 6-7 to be estimated quantitatively. On the other hand, flagellates appeared first only on Day 7.5 in the Laminaria pallida incubation and could be estimated quantitatively on Day $7-8$ by 
Table 4. Dry biomass of micro-organisms ( $\mathrm{mg} \mathrm{l}^{-1}$ ) measured at daily intervals for $28 \mathrm{~d}$ in seawater and in incubation media to which $7.2 \mathrm{~g} \mathrm{l}^{-1}$ of dried mucilage from Laminaria pallida had been added. Net total heterotroph biomass obtained by subtraction of total heterotroph biomass in seawater controls from those to which mucilage had been added

\begin{tabular}{|c|c|c|c|c|c|c|c|c|c|c|c|}
\hline \multirow[t]{2}{*}{ Days } & \multicolumn{5}{|c|}{ Seawater control } & \multicolumn{5}{|c|}{ Seawater + mucilage } & \multirow{2}{*}{$\begin{array}{c}\text { Net total } \\
\text { hetero- } \\
\text { trophs }\end{array}$} \\
\hline & Bacteria & $\begin{array}{c}\text { Flagel- } \\
\text { lates }\end{array}$ & Ciliates & Diatoms & $\begin{array}{l}\text { Total he- } \\
\text { terotrophs }\end{array}$ & Bacteria & $\begin{array}{c}\text { Flagel- } \\
\text { lates }\end{array}$ & Ciliates & Diatoms & $\begin{array}{l}\text { Total he- } \\
\text { terotrophs }\end{array}$ & \\
\hline 1 & 0.084 & - & - & - & 0.084 & 0.490 & - & - & - & 0.490 & 0.406 \\
\hline 2 & 0.116 & - & - & - & 0.116 & 0.977 & - & - & - & 0.977 & 0.861 \\
\hline 3 & 0.196 & - & - & - & 0.196 & 4.525 & - & - & - & 4.525 & 4.329 \\
\hline 4 & 0.233 & - & - & - & 0.233 & 9.064 & - & - & - & 9.064 & 8.831 \\
\hline 5 & 0.317 & 0.002 & -- & 0.100 & 0.317 & 22.088 & - & - & - & 22.088 & 21.771 \\
\hline 6 & 0.385 & 0.006 & - & 0.198 & 0.385 & 20.592 & - & - & - & 20.592 & 20.207 \\
\hline 7 & 0.695 & 0.015 & - & 1.083 & 0.695 & 30.448 & - & - & - & 30.448 & 29.753 \\
\hline 8 & 0.499 & 0.020 & - & 1.634 & 0.499 & 76.890 & - & - & - & 76.890 & 76.391 \\
\hline 9 & 0.353 & 0.026 & - & 2.781 & 0.353 & 92.092 & - & - & - & 92.092 & 91.739 \\
\hline 10 & 0.416 & 0.034 & - & 2.851 & 0.416 & 80.850 & - & 0.304 & - & 81.154 & 80.738 \\
\hline 11 & 0.471 & 0.028 & - & 2.956 & 0.471 & 68.805 & 0.125 & 1.762 & - & 70.692 & 70.221 \\
\hline 12 & 0.571 & 0.032 & 0.009 & 1.819 & 0.580 & 50.424 & 0.337 & 4.558 & - & 55.319 & 54.739 \\
\hline 13 & 0.294 & 0.022 & 0.016 & 1.286 & 0.310 & 27.852 & 1.823 & 5.893 & - & 35.568 & 35.258 \\
\hline 14 & 0.271 & 0.020 & 0.014 & 0.371 & 0.285 & 0.818 & 2.415 & 7.564 & - & 10.797 & 10.512 \\
\hline 15 & 0.106 & 0.002 & 0.010 & - & 0.116 & 0.729 & 2.185 & 6.840 & - & 9.754 & 9.638 \\
\hline 16 & 0.040 & - & 0.015 & - & 0.055 & 2.277 & 1.705 & 7.096 & - & 11.078 & 11.023 \\
\hline 17 & 0.016 & - & 0.008 & - & 0.024 & 0.878 & 0.569 & 7.373 & - & 8.820 & 8.796 \\
\hline 18 & 0.017 & - & - & - & 0.017 & 0.136 & 0.593 & 6.728 & - & 7.403 & 7.386 \\
\hline 19 & 0.006 & - & - & - & 0.006 & 0.105 & 0.748 & 4.412 & - & 5.265 & 5.259 \\
\hline 20 & 0.004 & - & - & - & 0.004 & 0.105 & 0.862 & 0.813 & - & 1.780 & 1.776 \\
\hline 21 & 0.004 & - & - & - & 0.004 & 0.139 & 0.633 & 0.976 & - & 1.748 & 1.744 \\
\hline 22 & 0.002 & - & - & - & 0.002 & 0.180 & 0.320 & 0.824 & - & 1.324 & 1.322 \\
\hline 23 & 0.003 & - & - & - & 0.003 & 0.163 & 0.250 & 0.549 & - & 0.962 & 0.959 \\
\hline 24 & 0.004 & - & - & 0.034 & 0.004 & 0.209 & 0.282 & 0.466 & - & 0.957 & 0.953 \\
\hline 25 & 0.005 & - & - & 0.055 & 0.005 & 0.139 & 0.230 & 0.521 & - & 0.890 & 0.885 \\
\hline 26 & 0.005 & - & - & 0.196 & 0.005 & 0.194 & 0.213 & 0.510 & - & 0.917 & 0.912 \\
\hline 27 & 0.006 & - & - & 0.541 & 0.006 & 0.123 & 0.084 & 0.490 & - & 0.897 & 0.891 \\
\hline 28 & 0.005 & - & - & 0.758 & 0.005 & 0.132 & 0.070 & 0.516 & - & 0.718 & 0.713 \\
\hline
\end{tabular}

Table 5. Maximum values for bacterial prey density and ciliate-plus-flagellate predator density ( $\mathrm{mg}$ dry mass $\mathrm{1}^{-1}$ ) in seawater containing approximately $2 \mathrm{~g}$ organic matter $\mathrm{l}^{-1}$ from kelp (Ecklonia maxima and Laminaria pallida) mucilage. Data compiled from Tables 3 and 4

\begin{tabular}{|lccc|}
\hline $\begin{array}{l}\text { Source } \\
\text { of mucilage }\end{array}$ & $\begin{array}{l}\text { Source of } \\
\text { seawater }\end{array}$ & $\begin{array}{c}\text { Biomass of } \\
\text { bacteria } \\
\left(\mathrm{mg} \mathrm{l}^{-1}\right)\end{array}$ & $\begin{array}{c}\text { Biomass of } \\
\text { ciliates } \\
\text { flagellates } \\
\left(\mathrm{mg} \mathrm{l}^{-1}\right)\end{array}$ \\
\hline $\begin{array}{l}\text { Ecklonia } \\
\text { maxima }\end{array}$ & $\begin{array}{l}\text { August } \\
\text { (winter) }\end{array}$ & 22.045 & 1.433 \\
$\begin{array}{l}\text { Laminaria } \\
\text { pallida }\end{array}$ & $\begin{array}{l}\text { August } \\
\text { (winter) }\end{array}$ & 34.959 & 2.855 \\
$\begin{array}{l}\text { Laminaria } \\
\text { pallida }\end{array}$ & $\begin{array}{l}\text { February } \\
\text { (sumner) }\end{array}$ & 91.739 & 9.965 \\
\hline
\end{tabular}

which time the bacterial population was approximately $30 \%$ larger than the maximum achieved in the E. maxima mucilage. The population of flagellates then increased rapidly and exceeded that in the $E$. maxima mucilage before declining on Day 11. Findily, in the summer incubation experiments on L. pallida mucilage, flagellates and ciliates appeared almost synchronously on Days 10-11 by which time the bacterial population was almost $3 \times$ the maximum biomass formed when the same mucilage was incubated in seawater collected during the winter. This was followed by the appearance of a large mixed population of flagellates and ciliates whose combined grazing activity reduced the bacterial population to a negligible biomass in approximately $10 \mathrm{~d}$.

The relationship between the maximal bacterial biomass formed under incubation conditions and the maximal flagellate and ciliate biomass is shown in Figure 4. In order to estimate the conversion efficiency of kelp mucilage into bacterial biomass, it is clearly necessary to determine both substrate utilisation and bacterial biomass synchronously. These data are reported in the subsequent paper by Lucas et al. (1981). It is, however, possible from the present data to estimate the maximal population of Protozoa which is associated with the bacterial population under these 
culture conditions. These data, summarised in Table 5 , reveal that the maximum biomass formed by the flagellates and ciliates ranges from 5 to $11 \%$ of the maximal bacterial population.

\section{CONCLUSION}

Micro-organisms which colonise incubation media containing mucilage from the kelps Ecklonia maxima and Laminaria pallida show a clear succession. The mucilage is first colonised by bacterial cocci followed by rods which are subsequently replaced by flagellates and ciliates whose combined biomass reaches some 6 to $10 \%$ of that of the bacteria. Similar sequential colonisation of plant debris has been widely reported in the literature on freshwater ecosystems (e.g. Kaushik and Hynes, 1971; Bick and Müller, 1973; Lock and Hynes, 1976; Hayes, 1979). It seems likely that these common patterns are due mainly to the fact that higher trophic levels in the microheterotrophic food chain are dependent on the initial establishment of primary decomposers such as fungi and bacteria. These may, in turn, represent important components in the transfer of energy to higher trophic levels through grazing flagellates and ciliates to copepods and fishes (see Berk et al., 1976, 1977; Berk and Colwell, 1981).

The sequential appearance of grazing flagellates in our incubation media also gives some indication of the rate of consumption of bacteria by flagellates. Figure 5 shows the curve obtained for bacterial biomass in the absence of ciliates or flagellates; superimposed are curves illustrating the biomass of bacteria in each of the incubation experiments in the presence of known increasing biomass of flagellates and ciliates (see also Tables 3 and 4). Clearly, in the case of the Ecklonia maxima incubation experiment, the biomass of bacteria was held almost constant over a period of $4 \mathrm{~d}$ during which time the predator biomass was sustained by bacterial production and increased from $0.215 \mathrm{mg}$ $\mathrm{l}^{-1}$ to $1.143 \mathrm{mg} \mathrm{l}^{-1}$. In both of the Laminaria pallida incubation experiments, however, the population of flagellates and ciliates increased so rapidly that the population of bacteria diminished sharply; presumably the bacterial production was unable to meet the demands of the predator population.

Burkill (1978) has found that the daily consumption of the ciliate Uronema marinum from Southampton water is approximately $6 \times$ its body weight day ${ }^{-1}$, estimated for a ciliate of $1000 \mu \mathrm{m}^{3}$. In contrast, the body volume of the small flagellates which colonised the incubation media containing mucilage from Ecklonia maxima had a mean volume of only $9.94 \mu \mathrm{m}^{3}$. Since consumption and metabolism follow a well-known size dependent relationship of $W^{0.75}$, it is likely that grazing and subsequent mineralisation of marine bacteria by the micro-flagellates approaches $35 \times$ the body weight day $^{-1}$, and thus may considerably exceed that by the large Protozoa at higher trophic levels.

Acknowledgements. We are particularly grateful to the staff of the EM Unit, University of Cape Town, South Africa, for extensive use of their facilities and for funds from SANCOR without which this work could not have been carried out. Drs J. McN Sieburth and P. Hargraves have kindly assisted in the identification of some of the micro-organisms. We acknowledge financial support for E. A. S. Linley from a NERC postgraduate studentship and for R. C. Newell from a Senior Research Fellowship of the Royal Society.

\section{LITERATURE CLTED}

Anderson, T F. (1951). Techniques for the preservation of three-dimensional structure in preparing specimens for the electron microscope. Trans. N.Y, Acad. Sci. (Ser. II.) 13: $130-134$

Berk, S. G., Brownlee, D. C., Heinle, D. R., Kling, H. J., Colwell, R. R. (1977). Ciliates as a food source for marine planktonic copepods. Microb. Ecol. 4: 27-40

Berk, S. G., Colwell, R. R. (1981). Transfer of mercury through a marine microbial food web. J. exp. Ecol., in press

Berk, S. G., Colwell, R. R., Small, E. B. (1976). A study of feeding responses to bacterial prey by estuarine ciliates. Trans. Am. microsc. Soc. 95 (3): 514-520

Bick, H., Müller, H. P. (1973). Population dynamics of bacteria and protozoa associated with the decay of organic metter. Bull. Ecol. Res. Comm Natl. Sci. Res. Counc. (Swed.) 17: 379-386

Bowden, W. B. (1977). Comparison of two direct-count techniques for enumerating aquatic bacteria. Appl. environ. Microbiol. 33 (5): 1229-1232

Burkill, P. H. (1978). Quantitative aspects of the ecology of marine planktonic ciliated protozoans with special reference to Uronema marinum Dujardin. Ph. D. thesis, University of Southampton

Calkins, G. N., Summer, F. M. (eds) (1941). Protozoa in biological research, Columbia University Press, New York

Cundell, A. M., Sleeter, T D., Mitchell, R. (1977). Microbial populations associated with the surface of the brown alga Ascophyllum nodosum. Microb. Ecol. 4: 81-91

Ducklow, H. W (1977). Influence of sublethal pollutant concentrations on the microbial ecology of living corals. Ph. D. thesis, Harvard University, Cambridge

Fenchel, T. (1969). The ecology of marine microbenthos. IV. Structure and function of the benthic ecosystem, its chemical and physical factors and the microfauna communities with special reference to the ciliated protozoa. Ophelia 6 : $1-182$

Fenchel, $T(1970)$. Studies on the decomposition of organic detritus derived from the turtle grass Thalassia testudinum. Limnol. Oceanogr. 15: 14-20

Fenchel, T M., Jørgensen, B. B. (1976). Detritus food chains of aquatic ecosystems. The role of bacteria. Adv. microbial Ecol. 1: 199-206

Field, J. G., Griffiths, C. L., Linley, E. A. S., Carter, R. A., Zoutendyk, P. (1980). Upwelling in a nearshore marine ecosystem and its biological implications. Estuar. \& coast. mar. Sci. II: 133-150

Hayes, A. J. (1979). The microbiology of plant litter decomposition. Sci. Progr., London 66 (261): 25-42 
Hobbie, J. E., Daley, R. T., Jasper, S. (1977). Use of Nuclepore filters for counting bacteria by fluorescence mucroscopy. Appl. environ. Microbiol. 33 (5): 1225-1228

Jones, J. G., Simon, B. M. (1975). An investigation of errors in direct counts of aquatic bacteria by epifluorescence microscopy with reforence to a new method for drying membrane filters. J. appl Bact. 39: 1-13

Kauchik, N. K. Hynes, H. B. N. (1971). The fate of the dead leaves that fall into streams. Arch. Hydrobiol. 68 (4): $465-515$

Larsson, U., Hagström, A. (1979). Phytoplankton exudate release as an energy source for the growth of pelagic bacteria. Adv. microbıal Ecol. 1- 1-49

Laycock, R. A. (1974). The detrital food chain based on seaweeds. I Bacteria associated with the surface of Laminaria fronds. Mar Biol. 25: 223-231

Lock, M. A., Hynes, H. B. N. (1976). The fate of dissolved' organic carbon derived from autumn-shed maple leaves (Acer saccharum) in a temperate hard-water stream. Limnol. Oceanogr 21 (3): 436-443

Lucas, M. I., Newell, R. C., Velimirov, B. (1981). Heterotrophic utulisation of muclage released during fragmentation of kelp (Ecklonia maxima and Laminaria pallida). II. Differential utilisation of dissolved organic components from kelp mucllage. Mar. Ecol. Prog. Ser. 4. 43-55

Luria, S. E. (1960). The bacterial protoplasm: composition and organisation. In: Gunsalus, I. C., Stanier, R. Y (eds) The bacteria, Vol. 1 Academic Press, New York, pp. 1-34

Mazure, H. G. F. (1978). The seasonal cycle of marine bacteria in a west-coast kelp bed. Trans. R. Soc. S. Afr. 43: 119-124
Mazure, H. G. F., Field, J. G. (1980). Density and ecological importance of bacterta on kelp fronds in an upwelling region. J. exp. mar Biol. Ecol. 43: 173-182

Meyers, S. P., Hopper, B. E. (1973). Nematological-microbial interrelationships and estuarme brodegradatuve processes. In: Stevenson, L. H., Colwell, R. R. (eds) Estuarine microbial ecology. University of South Carolina Press, Columbia, pp. 48.3-489

Newell, R. C. (1979). Biology of intertudal anımals, 3rd ed., Marine Ecological Surveys, Faversham, Kent

Newell, R. C., Lucas, M. I, Velimirov, B., Seiderer, L. J. (1980). The quantilative significance of dissolved organic losses following fragmentation of kelp (Ecklonia maxima and Lammana pallida). Mar Ecol. Progr Ser. 2: 45-59

Paerl, H. W (1975). Microbial attachment to particles in marine and freshwater ecosystems. Microb. Ecol. 2: 73-83

Sieburth, J. McN. (1979). Sea microbes, Oxford University Press, New York

Sieburth, J. McN., Thomas, C. D. (1973). Fouling on eelgrass (Zostera marina L). J. Phycol. 9: 46-50

Sorokin, Y 1., Kadota, H. (eds) (1972). Technıques for the assessment of microbial production and decomposition in fresh waters. I. B. P. Handbook (23), Blackwell, Oxford

Todd, R. L., Kerr, T. J. (1972). Scanning electron microscopy of microbial cells on membrane filters. Appl Microb. 23 (6): $1160-1162$

Troltsky, A. S., Sorokin, Y I. (1967). On the methods of the calculation of the bacterial biomass in water bodies. Trans. Inst. Biol. Inland Waters. Acad. Sci. USSR 19 : $85-90$

This paper was presented by Professor R. C. Newell; it was accepted for printing on October 28, 1980 